\title{
Könyvszemle
}

\author{
Pilling János:
}

\section{Orvosi kommunikáció a gyakorlatban}

\author{
(Medical communication in practice) \\ Medicina Könyvkiadó Zrt., Budapest, 2018 \\ 324 oldal, $4100 \mathrm{Ft}$ \\ ISBN 978-963-226-700-5
}

Az elmúlt évtizedekben tapasztalható fejlődésnek köszönhetően a hazai orció. Az erről szóló tankönyvek azonban legtöbbször vaskosak, nehezen átláthatóak. Éppen ezért örültem, amikor először a kezembe fogtam Pilling János könyvét, amely első ránézésre is, még hallgató szemmel is emészthető, áttekinthető 324 oldalt foglal magába. A tankönyv legfontosabb pozitívuma a címében is szereplő, annak gyakorlatiasságára történő utalás, amelyet azután az olvasás is alátámaszt. A könyvvel tovább ismerkedve, a tartalomjegyzéket olvasva már egyértelmúen látható az is, hogy olyan témakörök is szerepet kapnak, amelyek az orvosi kommunikáció oktatásában gyakran háttérbe szorulnak, és amelyeket a korábbi tankönyvek nem tartalmaznak. Ilyen például a betegbiztonság kommunikációs kérdései és a komplementer módszereket használó betegekkel történő kommunikáció is. Ezeken túl, személyes kedvencem, a szuggesztív kommunikáció, amely témáról korábban már külön kötet is megjelent hazánkban. ${ }^{1}$

A kötet terjedelme összesen 315 oldal, valamint a tárgymutató. Egyetlen szerző munkája, talán ennek köszönhető, hogy nagyon átlátható és logikus a felépítése. Rendkívül sokoldalú tankönyv, összesen 19 plusz kettő, a tankönyv saját weboldalán olvasható fejezetből áll. Az 1. fejezet az orvosi kommunikáció jelentőségének bemutatásával vezeti be a könyvet. A 2. fejezet az orvos-beteg konzultáció gyakorlatát, a 3. fejezet az életmódváltás támogatásához használható eszközöket, a 4. fejezet pedig az egészségfejlesztés kommunikációs lehetőségeit mutatja be. Az 5. fejezet egy újszerú témáról, a kezelések kockázatával kapcsolatos kommunikációról, míg a 6. a közös döntéshozatalról szól. Ezeket követi a 7. fejezet, a szuggesztív kommunikáció szerepéról az orvosi gyakorlatban. Ez a téma azonban nem csak ezen a né-

\footnotetext{
1 Varga K. (Szerk.) (2011). A szavakon túl. Kommunikáció és szuggesztió az orvosi gyakorlatban. Budapest: Medicina Könyvkiadó
} 
hány oldalon jelenik meg, a könyvben végig kiemelt szerepet kap: az olvasó nagyon gyakorlatias és egyszerúen érthetô módszereket, tanácsokat kap az egyes technikák alkalmazásához. A könyvben tovább haladva, a 8. fejezetben az életkorra specifikus kommunikáció sajátosságairól, majd a 9.-ben ezzel szoros összefüggésben a kulturális kompetenciáról olvashatunk. A 10. izgalmas fejezet a komplementer és alternatív módszereket használó betegekkel történő kommunikációhoz ad tanácsokat, majd a 11. fejezet a funkcionális tünetekkel rendelkező páciensek kezelésével kapcsolatos kérdéseket tárgyalja. A 12. fejezettól a tankönyv az orvosi kommunikáció talán legnehezebb témáit járja körbe, kezdve az intim, szexualitással kapcsolatos kérdésektől, az indulatos betegekkel való kommunikáción át a mentális zavarokkal küzdő emberekkel történő kommunikációig. A sor folytatódik a 15. fejezetben a rossz hírek közlésével, majd a 16. fejezetben a betegbiztonság vonatkozásaival, a 17. fejezetben a fogyatékkal éló emberek, és a 18. fejezetben az abúzus áldozatainak kommunikációjával. Látható tehát, hogy olyan gyakran kikerült, nehéz témák is előkerülnek a könyvben, amelyek a gyakorlatban sokszor háttérbe szorulnak, és ahol az eszköztelenség érzése fokozza a feszültséget nemcsak a páciensekben, de a szakemberekben is. Végül, a 19. fejezetben a szerző egy könnyedebb, innovatív témával, az e-health módszerei és eszközei felhasználási lehetőségének bemutatásával zárja a könyvet. A www.orvosikommunikacio.hu oldalon továbbá egy a könyvhöz tartozó egyedi kóddal megtekinthető két extra fejezet is, amelyekben az orvos-beteg kommunikációról kissé más perspektívából, orvostanhallgatói szemmel olvashatunk.

A könyv tartalmán túl, számomra kifejezetten tetszett a fejezetek szerkezete. Fontos kiemelni ugyanis, hogy minden fejezetnek meghatározott szerkezete van, az ún. PQRST (Preview, Question, Read, Self-recitation, Test) tanulást segító módszer felhasználásával. Ez azt jelenti, hogy minden fejezet egy áttekintéssel, tartalomjegyzékkel indul, majd a fejezet alcímei már megfogalmaznak egy kérdést, amelyet követ maga az olvasás, a szövegtörzs, az alapfogalmak és kulcsüzenetek. Ezt követően az olvasónak lehetőséget ad a könyv az ismétlésre, és végül az ellenőrzésre. Ez a felépítés jelentősen megkönnyítheti a hallgatók számára a felkészülést és a mélyebb tanulást. A tankönyv egyébként is végig átlátható, jól strukturált és logikusan felépített. A kiemelések segítik a figyelmet a legfontosabb fogalmakra irányítani, az információ önkéntelenül is megragad az olvasó fejében. A szerző számos modellt mutat be, de ezeket nem szárazon, a klasszikus tankönyvi formában írja le, hanem példákkal illusztrálva, ráadásul a legtöbb ezek közül könnyen megjegyezhetô mozaikszó. A tárgymutató jól használható, a legfontosabb fogalmakat és modelleket tartalmazza. Az „Érdemes utánanézni” részfejezetek között számomra is új, innovatív eszközökre, információkra (pl. Watson, az IBM mesterséges intelligenciaprogramja) bukkantam, ame- 
lyek nemcsak hasznosak, de érdekesek is. Ismét, a klasszikus tankönyveket jelentősen meghaladja ez a fajta megoldás, hiszen a hagyományosan ajánlott olvasmányokat élvezetes, gyakorlatközpontú módon teszi megismerhetővé. A könyv gyakorlati jelentőségét és interaktív mivoltát erősíti, hogy saját weboldallal rendelkezik, ahol bejelentkezés után lehetőség nyílik a könyv olvasására, videók és az extra fejezetek megtekintésére. Ezek mellett az oldalon egy kvízjáték is elérhető, amelynek segítségével játékos formában tanulhatóak az „OK világ” legfontosabb fogalmai.

Fontos azonban, hogy a tankönyv nem csupán beteg- és hallgatóközpontú, de „orvos- és oktatóközpontú" is, hiszen számos olyan információt tartalmaz, amely pont az orvosok egészségét, a kiégés megelőzését segíti elő, illetve speciális szerkezete didaktikailag az oktató számára is megkönnyíti az egyes témák átláthatóságát, az Érdemes utánanézni részek pedig lehetőséget adnak érdekességekkel színezni az órákat és felmérni a hallgatók motiváltságát. Az egyetlen kiegészítő, a témában született tankönyvekre általánosságban igaz észrevételem, hogy érdemes lenne talán a témát egy másik perspektívából is körbejárni, az orvos-orvos és orvos-egészségügyi szakdolgozó szempontjából, hiszen az a tapasztalat, hogy az igazi nehézséget gyakran nem a betegekkel, hanem a kollégákkal történő kommunikáció okozza.

Összességében tehát egy hazai és nemzetközi viszonylatban is kiemelkedő színvonalú tankönyvet kaptunk „kezdőknek és haladóknak” egyaránt, amely jelentősen megkönnyítheti az orvosi kommunikáció oktatását és tanulását.

Gács Boróka

E-mail: boroka.gacs@aok.pte.hu 